\title{
Peningkatan Kesehatan Reproduksi bagi Wanita Usia Subur dalam Upaya Pencegahan Ca.Cerviks di Kelurahan Murni Kecamatan Danau Sipin Jambi
}

\author{
Nurfitriani \\ Program Studi DIII Keperawatan STIKes Baiturrahim \\ email:nurfitriani_1173@yahoo.com
}

Submitted : 12/11/2019

Accepted: 19/11/2019

Published: 31/01/2020

\begin{abstract}
Currently Indonesia is undergoing a change in the pattern of diseases called epidemiological transitions characterized by increased mortality and illness due to non-communicable diseases (PTM) such as stroke, heart disease, diabetes, cancer and others. Cancer is a group of noncommunicable diseases caused by growth body cells that are not normal. Cancer is the leading cause of death in the world, and. most cancers experienced by women is cervical cancer. According to experts, cervical cancer is one of the most preventable and treatable types of cancer. Risk factors for cancer include: genetic factors, infectious factors, lifestyle factors, and physical activity factors. Therefore, pre-cancerous lesion screening is very important because the treatment can cure up to 100\%. Whereas in invasive cancer, the use of lesions gives less satisfactory results with a life expectancy of 5 years, which is between $20 \%-90 \%$. Based on field observations and interviews with Posbindu cadres, information was obtained that there were still many mothers who had not done IVA tests, for reasons they did not know, were ashamed and were afraid if they later discovered the type of disease they were suffering from. The target of this activity is the Posbindu group in RT 14 and 15, Kelurahan Murni. Kecamatan Danau Sipin, amounting to 15 people. The purpose of this community service after socialization and health education is able to understand and be motivated and take part in conducting IVA test. The results obtained with the socialization and health education of post cadre cadre leaders and members and the community increase knowledge and behavior changes.
\end{abstract}

Keywords: Ca. Cerviks, IVA Test

\begin{abstract}
Abstrak
Saat ini Indonesia tengah mengalami perubahan pola penyakit yang disebut transisi epidemiologi yang ditandai dengan meningkatnya kematian dan kesakitan akibat penyakit tidak menular (PTM) seperti, stroke, jantung, diabetes,kanker dan lain-lain.Kanker merupakan kelompok penyakit tidak menular yang disebabkan oleh pertumbuhan sel-sel tubuh yang tidak normal. Kanker merupakan penyebab kematian terbanyak di dunia, dan. kanker yang banyak dialami kaum perempuan adalah kanker serviks. Menurut para ahli, kanker serviks merupakan salah satu jenis kanker yang paling bisa dicegah dan bisa diobati. Faktor resiko terjadinya kanker meliputi : faktor genetic, faktor infeksi, faktor gaya hidup, dan faktor aktivitas fisik. Oleh karena itu, skrining lesi pra kanker sangat penting sekali karena pengobatannya bisa menyembuhkan sampai $100 \%$. Sedangkan pada kanker invasif, penggunaan lesi memberikan hasil yang kurang memuaskan dengan harapan hidup 5 tahun, yaitu antara 20\%-90\%. Berdasarkan observasi di lapangan dan wawancara dengan para kader Posbindu diperoleh keterangan masih banyak ibu ibu belum mlakukan pemeriksaan tes IVA, karena alasan belum tahu, malu dan takut jika nanti ketahuan jenis penyakit yang dideritanya. Sasaran kegiatan ini adalah kelompok Posbindu di RT 14 dan 15 kelurahan Murni kec. Danau Sipin yang berjumlah 15 orang. Tujuan dari pengabdian masyarakat ini setelah melakukan sosialisasi dan pendidikan kesehatan mampu memahami dan termotivasi serta ikut serta dalm melakukan tes IVA .Hasil yang diperoleh dengan adanya sosialisasi dan pendidikan kesehatan ketua kader posbindu dan anggota serta masyarakat terjadi peningkatan pengetahuan dan perubahan perilaku.
\end{abstract}

Kata Kunci: Ca. Cerviks, Tes IVA 


\section{PENDAHULUAN}

Saat ini Indonesia tengah mengalami perubahan pola penyakit yang disebut transisi epidemiologi yang ditandai dengan meningkatnya kematian dan kesakitan akibat penyakit tidak menular (PTM) seperti, stroke, jantung, diabetes,kanker dan lain-lain. Berdasarkan Data Riset Kesehatan Dasar (Riskesdas) tahun 2013, prevalensi tumor atau Kanker di Indonesia adalah 1,4 per 1000 penduduk. Prevalensi tertinggi terdapat di Yogyakarta $(4,1 \%)$, diikuti jawa tengah $(2,1 \%)$, Bali (2\%), dan DKI Jakarta masing - masing 1,9 per mil.

Kanker tertinggi di Indonesia pada perempuan adalah kanker payudara dan kanker leher rahim. Tingginya angka kesakitan kanker leher rahim di Indonesia yaitu 12,6 / 100000 perempuan dengan angka kematian $7 /$ 100000, sedangkan angka kesakitan dan kanker payudara di Indonesia yaitu insiden rate 36,2/ 100000 perempuan dengan mortality rate 18,6/ 100000 perempuan menurut IARC tahun 2008.

Pada tahun 2009 di Jawa Timur jumlah kasus kanker serviks mencapai 1879 kasus yang terdiri atas 1185 orang menjalani rawat inap dan 694 orang rawat jalan. Angka tersebut mendudukkan Jawa Timur sebagai peringkat pertama kanker leher rahim tingkat nasional.

Menurut para ahli kanker, kanker serviks merupakan salah satu jenis kanker yang paling bisa dicegah dan bisa diobati. Faktor resiko terjadinya kanker meliputi : faktor genetic, faktor infeksi, faktor gaya hidup, dan faktor aktivitas fisik. Oleh karena itu, skrining lesi pra kanker sangat penting sekali karena pengobatannya bisa menyembuhkan sampai $100 \%$. Sedangkan pada kanker invasif, penggunaan lesi memberikan hasil yang kurang memuaskan dengan harapan hidup 5 tahun, yaitu antara 20\%-90\% (Subagja, 2014).
Dinas Kesehatan (Dinkes) Provinsi Jambi mencatat 284 perempuan terdeteksi positif kanker serviks setelah melalui pemeriksaan Inspeksi Visual Asam (IVA) yang dilakukan dalam kurun waktu 2016 2017. Bidang Pencegahan dan Pengendaliaan Penyakit pada Dinkes Provinsi mengatakan bahwa dari 8.525 wanita menikah dengan usia subur rentang 30 - 50 tahun yang di periksa melalui deteksi dini kanker mulut rahim (serviks) di antaranya 284 orang positif mengalami masalah reproduksi.

Untuk mengurangi angka morbiditas dan martalitas pada ibu, perlu adanya peran serta pemerintah dan swasta dalam meningkatkan derajat kesehatan masyarakat. Menurut para ahli kanker, kanker serviks merupakan salah satu jenis kanker yang paling bisa dicegah dan bisa diobati. Faktor resiko terjadinya kanker meliputi : faktor genetic, faktor infeksi, faktor gaya hidup, dan faktor aktivitas fisik. Oleh karena itu, skrining lesi pra kanker sangat penting sekali karena pengobatannya bisa menyembuhkan sampai $100 \%$. Sedangkan pada kanker invasif, penggunaan lesi memberikan hasil yang kurang memuaskan dengan harapan hidup 5 tahun, yaitu antara 20\%-90\% (Subagja, 2014).

Salah satu penyelenggaraan skrining kanker serviks adalah metode Inspeksi Visual dengan Asam Asetat (IVA) yang memiliki keakuratan 90\% (Rahma dan Prabandari, 2011). IVA adalah sebuah metode yang mudah untuk dipelajari, murah dan membutuhkan peralatan minimal daripada prasarana laboratorium dan memberikan hasil yang sebentar, sehingga akurat untuk mendiagnosa (Denny and Rengaswamy, 2006).

Dari hasil pantauan dan observasi di Kelurahan Murni Kecamatan Danau Sipin masih banyak ibu -ibu yang belum pernah melakukan tes IVA, bahkan ada yang belum tahu apa itu tes IVA dan prosedur 
pelaksanaanny, sehingga penulis tertarik mengangkat judul ' Peningkatan Kesehatan Reproduksi Bagi Wanita Usia Subur dalam Upaya Pencegahan Ca. Cerviks Di Kelurahan Murni Kecamatan Danau Sipin Jambi.'

Berdasarkan Latar belakang yang telah di uraikan di atas, maka dapat dirumuskan masalahnya adalah : Belum diketahuinya tingkat keberhasilan peningkatan derajat kesehatan reproduksi wanita dalam upaya pencegahan $\mathrm{Ca}$. Cerviks melalui pemeriksaan tes IVA di Kelurahan Murni Kecamatan Danau Sipin Jambi.

\section{TARGET DAN LUARAN}

\section{A. Target}

Peningkatan derajat kesehatan masyarakat Indonesia khususnya masyarakat di RT 14 dan 15 Kelurahan Murni Kecamatan Danau Sipin, maka perlu adanya peran petugas kesehatan maupun Perguruan tinggi terutama dalam bidang kesehatan bersama sama menyelesaikan permasalahan yang ada di masyarakat terutama masalah penyakit tidak menular salah satunya pencegahan Ca.Cerviks melalui tes IVA. Agar pemeriksaan atau Tes IVA yang dilaksanakan sebagai pencegahan / deteksi dini dari kejadian $\mathrm{Ca}$. Cerviks, maka diupayakan adanya pemberian edukasi di masyarakat RT 14 dan 15 Kelurahan Murni. Kegiatan edukasi ini bertujuan untuk membantu petugas kesehatan khususnya Puskesmas dalam memberikan pendidikan kesehatan/ edukasi dan mensosialisasikan pemeriksaan Tes IVA yang di khususkan untuk wanita usia subur yang sudah menikah atau yang telah aktif melakukan hubungan seksual agar terhindar dari $\mathrm{Ca}$. Cerviks.Adapun target kegiatannya meliputi ;

1. Ibu-ibu warga RT 14 dan 15 Kelurahan Murni datang ke Posyandu/ rumah warga yang ditunjuk dalam acara arisan (40\% Hadir)

2. Identifikasi Kegiatan yang ada dan dilaksanakan warga RT ( pengajian setiap bulan, senam aerobik setiap minggu(60\% terlaksana)

3 Masyarakat RT 14 dan 15 dapat memanfaatkan sarana layanan kesehatan yang tersedia (15\% terlaksana) .

4 Pelaksanaan penyuluhan kesehatan yang awalnya jarang, sekarang

5. Ibu ibu yang hadir mau mengikuti kegiatan pemeriksaan tes IVA $(15 \%$ yang mau periksa tes IVA)

6 .Evaluasi Pmeriksaan kesehatan, sebelumnya jarang dilakukan

B. Luaran

Adapun hasil luaran yang dicapai dalam pengabdian kepada masyarakat meliputi :

a. Luaran Wajib akan dipublikasikan ke Jurnal Ilmiah Pengabdian (JAK ABDIMAS STIKBA) Jambi.

b. Terjadinya peningkatan pengetahuan dan perbaikan tata nilai di masyarakat khususnya Rt 14 dan 15Kelurahan Murni

c. Diketahuinya cakupan penyuluhan kelompok pada perempuan berusia 30 - 50 tahun di RT 14 dan 15 Kelurahan Murni Kecamatan Danau Sipin Jambi.

d. Diketahuinya cakupan penapisan kanker leher rahim pada perempuan berusia $30-50$ tahun melalui kesadaran dalam pemeriksaan tes IVA sedini mungkin.

e. Terlaksananya penyuluhan kesehatan tentang tes IVA sebagai upaya pencegahan Ca.Cerviks

f. Terlaksananya pemeriksaan tes IVA yang dipusatkan di Kecamatan Danau Sipin dengan bekerjasama dengan pihak Puskesmas (Hanya 8 ibu yang bersedia) 


\section{METODE PELAKSANAAN}

Kegiatan pengabdian masyarakat ini dilaksanakan di bulan Maret s/d Agustus 2018 bertujuan memberikan pengetahuan dan wawasan pada ibu ibu pasangan usia subur yang dilaksanakan di kelurahan Murni dengan dibantu 2 orang mahasiswa. Sasaran kegiatan pengabdian ini adalah kader Posbindu beserta Ibu ibu usia subur di RT 14 dan 15 Kelurahan Murni dengan target sasaran berjumlah 30 orang. Tujuan dari pengabdian masyarakat ini diharapkan setelah mendapatkan penyuluhan kesehatan ibu ibu kader dan warganya sehingga termotivasi untuk mengikuti pemeriksaan tes IVA.

Adapun metode pelaksanaan pengabdian kepada masyarakat yang dilakukan sesuai dengan rencana dapat di uraikan sebagai berikut :

1. Temu Pak Lurah, Ketua PKK dan Kader di Kelurahan Murni dalam rangka identifikasi kegiatan dan penjadwalan kegiatan

2. Perumusan Solusi : Identifikasi masalah warga Kelurahan terkait dengan kesehatan reproduksi, Srategi pelaksanaan kegiatan dan Pembuatan leaflet Pencegahan Ca.Cerviks melalui tes IVA

3. Pemberian Informasi /penyuluhan kesehatan: Pendidikan kesehatan tentang pemeriksaan IVA sebagai upaya pencegahan Ca.Cerviks

4. Evaluasi dan monitoring:

a. Warga antusias untuk mengikuti pendidikan kesehatan tentang tes IVA, Hanya 8 warga yang bersedia melakukan tes IVA setelah kegiatan berlangsung

b. Kegiatan ini bekerjasama dengan pihak Puskesmas Putri ayu

c. Pembinaan dan pengawasan oleh Puskesmas.

\section{HASIL DAN PEMBAHASAN}

Kegiatan yang dilaksanakan antara lain :

1. Mengadakan temu pengurus di Kelurahan Murni dan kader Kesehatan di Kelurahan Murni

2. Mengidentifikasi masalah kesehatan yang ada di Kelurahan Murni Kecamatan Danau Sipin Jambi

3. Hasil penyuluhan kesehatan yang telah diberikan rata-rata ibu telah memahami tehnik pemeriksaan Tes IVA.

4. Hasil identifikasi masih banyak ibuibu yang belum paham atau belum pernah melakukan pemeriksaan tes IVA.

Berdasarkan hasil penyuluhan kesehatan yang dilakukan dan dari diskusi bersama-sama ibu-ibu tersebut rata-rata ibu telah mengetahui manfaat tes IVA dalam pencegahan $\mathrm{Ca}$. Cerviks sebagai salah satu cara deteksi lebih dini dan tidak memerlukan biaya yang besar serta lebih praktis dan sederhana sehingga dapat mengetahui kesehatan reproduksi ibu itu sendiri dan jika terdeteksi maka pengobatanyang dilakukan dapat lebih optimal. Beberapa tahapan berikutnya yang perlu di lanjutkan dalam kegiatan penyuluhan ini antara lain:

1. Berkoordinasi dengan Kepala Kelurahan, Ketua PKK dan Kader dalam membangun kerja sama lanjutan untuk pengabdian masyarakat dan penelitian selanjutnya.

2. Bekerjasama dan berkoordinasi dengan instansi terkait, seperti Dinas Kesehatan Kota/ Provinsi, Puskesmas Puteri Ayu Jambi terkait dengan Pemeriksaan Tes IVA..

3. Monitoring dan evaluasi pelaksanaan Kegiatan. 


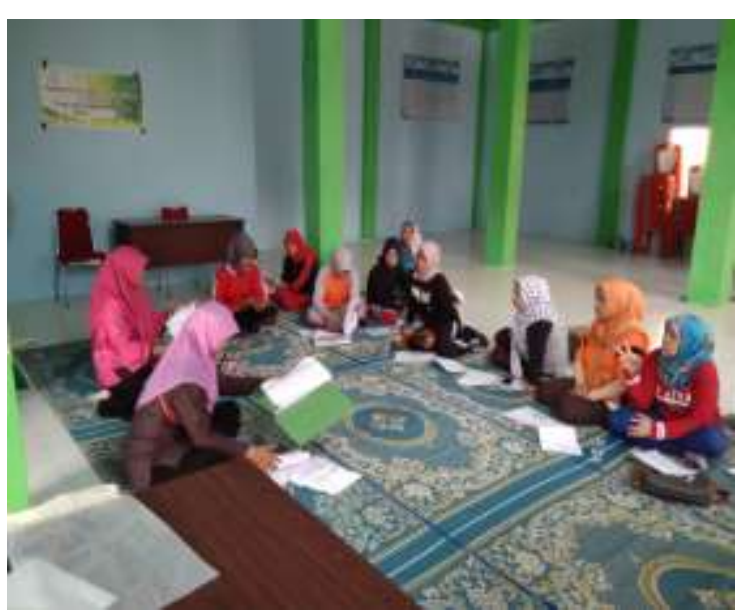

Gambar 1. Kegiatan penyuluhan

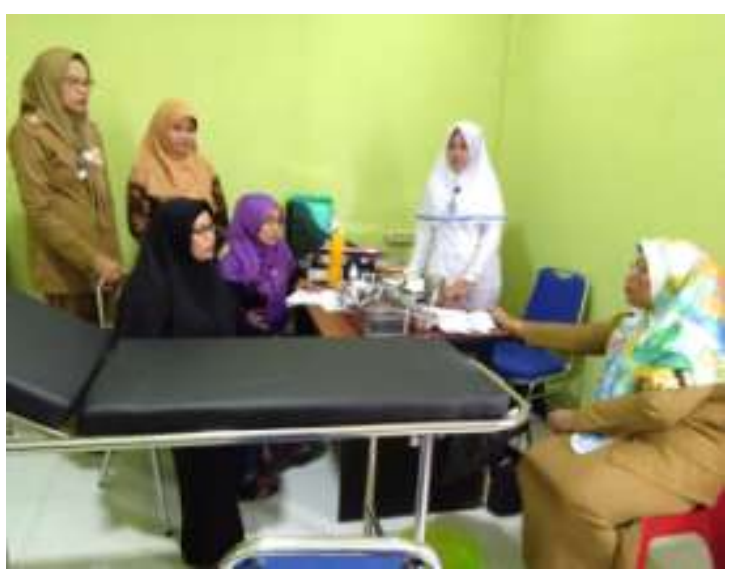

Gambar 2. Konsultasi pemeriksaan IVA Test

\section{KESIMPULAN DAN SARAN}

\section{A. Kesimpulan}

Dengan adanya pengabdian masyarakat di Kelurahan Murni ini, ibuibu dan kader termotivasi dan mau ikut serta kegiatan penyuluhan kesehatan khususnya tentang pemeriksaan tes IVA dan aktif dalam kegiatan lainnya.

Hasil pengabdian masyarakat ini adalah para kader dan ibu-ibu usia subur memahami dan mengerti tentang Tes IVA sebagai deteksi dini kanker serviks serta ada yang bersedia langsung memeriksakan diri dan semua ibu ibu dalam kondisi sehat.

\section{B. Saran}

1. Bagi Puskesmas Putri Ayu Jambi

Agar dapat lebih mengoptimalkan lagi peran puskesmas dalam memberikan pendidikan kesehatan khususnya tentang tes IVA sehingga program yang ada dapat terlaksana dan masyarakat paham dan ikut serta dalam program pemerintah tersebut

\section{Bagi Insitusi STIKBA Jambi}

Sebagai bahan bacaan dan kajian bagi ilmu kesehatan serta memotivasi bagi dosen agar dapat menjalankan perannya dalam Tridarma perguruan tinggi dan pengabdian masyarakat dan memotivasi mahasiswa ikut terlibat dalam pengabdian tersebut.

\section{DAFTAR PUSTAKA}

Afiyanti. 2016. Seksualitas dan Kesehatan Reproduksi Perempun. Promosi, Permasalahan dan Penanganannya dalam Pelayanan Kesehatan dan Keperawatan. Jakarta: Rajawali Pers

Denny, L dan Rengaswamy, S. 2006. Secondary Prevention of Cervical Cancer. International Journal of Gynecology and Obstetrics (2006) 94 (supplement 1), S65-S70 diakses pada tanggal 31 Mei 2017.

Ismarwati et all. 2011. Promosi Kesehatan dalam Meningkatkan Pengetahuan, Sikap dan Perilaku Deteksi Dini Kanker Serviks pada Ibu-Ibu Anggota Pengajian. Berita Kedokteran Masyarakat. Vol.27,No 2, Hal 66-74. URL : http://download.portalgaruda.org/article.php? article $=143309 \& \mathrm{val}=5017$, diakses pada tanggal 31 Mei 2017.

Laila, Nuranna. 2009. Skrining Kanker Serviks dengan Metode Alternatif : IVA. Jakarta : Majalah Cermin Dunia Kedokteran No. 133 
Jurnal Abdimas Kesehatan (JAK) Vol 2, No. 1, Januari 2020

Doi : $10.36565 /$ jak.v2i1.71

p-ISSN: 2655-9266

e-ISSN: 2655-9218

Manuaba et all. 2009. Memahami

Kesehatan Reproduksi Wanita

Ed.2. Jakarta : EGC

Chandra, I. A. (2009 ). Memahami

Kesehatan Reproduksi

wanita. Jakarta: Penerbit Buku

Kedokteran.

Marmi. (2011). Asuhan Kebidanan

Patologi. Yogyakarta: Pustaka

Pelajar . 